\title{
Gerald Arthur Pratley, OC (1923-2011)
}

\author{
By The Editor
}

Spring 2011 Issue of KINEMA

It is with great sadness that we announce the passing away of Gerald Pratley on 14 March 2011, the Associate Editor and co-founder of Kinema.

Gerald was born and educated in London, England. He came to Canada in 1946 to work for the National Film Board but soon found himself instead in Toronto working for the Canadian Broadcasting Corporation as a scriptwriter. In 1948, he became the CBC's first film critic and commentator. During this time he also became the first post-war chairman of the Toronto Film Society. He served as a jury member of various festival competitions, including the first Canadian Film Awards in 1949. In 1968, Gerald became the founderdirector of the Ontario Film Institute (OFI), a position he held for over two decades. The OFI became a model for the influential Cinematheque Ontario (now the TIFF Cinematheque in Toronto). From 1970 to 1975 Gerald was the director of the Stratford International Film Festival in Ontario, which later provided inspiration to the Toronto International Film Festival.

Gerald Pratley was made a member of the Order of Canada in 1984 and an Officer of the Order of Canada in 2003. In 1998, he was one of the first recipients of the Toronto Film Critics Association's Clyde Gilmour Award. He received a special Genie Award in 2002, in recognition of his decades of service to Canadian cinema.

A gifted storyteller and prolific writer, his major works include The Cinema of John Frankenheimer, The Cinema of Otto Preminger, The Cinema of David Lean, The Cinema of John Huston and Torn Sprockets, the authoritative history of the Canadian cinema.

Erudite and gentlemanly, Gerald was a relentless champion of good cinema in Canada and internationally. Above all, he was a great friend and colleague. He will be sincerely missed.

\section{The Editor}

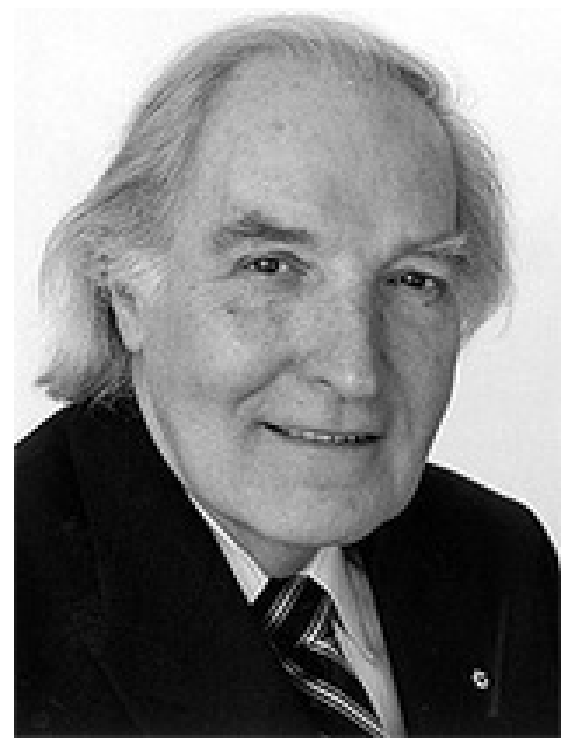

Figure 1: Gerald Pratley 


\section{Author Information}

Jan UHDE is Professor Emer. (Film Studies) at the University of Waterloo, Ontario, Canada. Born in Brno, Czech Republic. Graduated (MA) from the Faculty of Arts, Masaryk University, Brno; PhD received at the University of Waterloo, Ontario, Canada. He taught at the University of Waterloo (1970-2012) where he founded a General and Honours BA program in Film Studies at the Department of Fine Arts.

Publications: Latent Images: Film in Singapore Second edition, with Yvonne Ng Uhde (Ridge Books, National University Press of Singapore, 2010); Latent Images: Film in Singapore, with Yvonne Ng Uhde (Oxford University Press, 2000); Latent Images: Film in Singapore CD-ROM (2003, co-author); Vision and Persistence: Twenty Years of the Ontario Film Institute (University of Waterloo Press, 1990) and Ontario Film Institute Programming Activities Index 1969-1989 (Toronto: Ontario Science Centre, 1990). He co-edited the Place in Space: Human Culture in Landscape (Proceedings from the Second International Conference of the Working Group "Culture and Landscape" of the International Association of Landscape Ecology, Pudoc Scientific Publishers, Wageningen, Holland, 1993). Jan Uhde has published articles and reviews in several countries (including Canada, USA, Germany, Italy), participated in international juries at film festivals and presented papers at international conferences in North America and Europe. In 1998/99, he was a visiting researcher at the School for Film and Media Studies, Ngee Ann Polytechnic, Singapore.

His professional and research interests focus on Singapore cinema; the identification and distancing mechanisms of the film viewer; the non-authored modifications and manipulation of films; and specific aspects of film history, including the Central European cinema.

He founded KINEMA in 1993. 